\title{
MERAJUT JALAN TENGAH KERUKUNAN DALAM KOMUNIKASI LINTAS DAN ANTARBUDAYA DAN AGAMA DI INDONESIA
}

\author{
KNITTING THE MIDDLE ROAD OF HARMONY IN \\ COMMUNICATION OF CROSS-CULTURE AND INTER- \\ CULTURE AND RELIGION IN INDONESIA
}

\author{
Herman \\ Universitas Islam Negeri (UIN) Sunan Kalijaga Yogyakarta \\ e-mail: hermanfix590@gmail.com
}

\begin{abstract}
ABSTRAK
Dinamika hubungan umat manusia dengan latar belakang keagamaan dan budaya yang semakin kompleks dan seolah makin berpeluang dalam hadirnya beragam konflik. Memerlukan pemenuhan jalan keluar yang dalam hal ini perlu ditujukan kepada anak bangsa melalui edukasi beragam bentuk guna menanamkan pemahaman spiritualitas secara murni yang tidak lagi berada pada tataran fisik atau pakaian saja. Artikel ini bertujuan untuk mengeksplorasi secara umum halhal yang perlu untuk dilakukan dalam menyediakan pendidikan bagi generasi muda kita dalam hal komunikasi pembangunan agama, termasuk peran pemerintah selaku otoritas terkait dan tokoh-tokoh agama, masyarakat, dan medium komunikasi dalam melanggengkan pembangunan ini. Tentunya kontak yang berhubungan dengan antar dan lintas budaya dan agama di indonesia. Model multi-track communication sebagai salah satu alat edukasi yang mengintegrasikan beragam pendekatan diperlukan dalam hal ini. Sehingga dirasa bahwa penyunatan atas informasi dan pemikiran orang-orang yang berlatar belakang berbeda dari masing-masing individu bisa diminimalisir dengannya.
\end{abstract}

Kata Kunci: Komunikasi lintas antarbudaya dan agama

\begin{abstract}
The dynamics of human relations with religious and cultural backgrounds are increasingly complex and are more likely to arise in the presence of various conflicts. Checking the fulfillment of the solutions needed for the nation's children through various forms of education to instill a pure understanding of spirituality that no longer matches the physical level or clothing. Articles that need to be done in providing education for our young generation in terms of communication on
\end{abstract}


religious development, including the role of the government as the relevant authority and religious leaders, the community, and communication media in perpetuating this development. Of course, contacts related to intercultural and inter-cultural and religious relations in Indonesia. The multi-track communication model as one of the various integrated educational tools is needed in this regard. How to direct others about the information and thoughts of people with different backgrounds from each individual can be minimized related.

Keywords: Cross-cultural communication and religion

\section{Pendahuluan}

Sejak masa kanak-kanak, saya telah dihadapkan pada situasi dimana budaya dan kepercayaan minoritas hidup di dalam masyarakat dengan kebudayaan dan kepercayaan (agama) yang sama. Kenyataan ini membuka peluang pembacaan kita sebagai manusia yang dengan amat jelas memiliki beragam latar belakang yang sangat variatif. Sekecil apapun kelompok sosial yang kita diami. Setidaknya dalam sekup kebudayaan/budaya dalam arti yang luas. Termasuk praktik dan pemahaman keagamaan yang berbeda namun memiliki nama yang sama (mis. NU dan Muhammadiyah). Dari pengalaman yang saya punyai memang tidak menampakkan konflik secara fisik. Namun lebih dalam di balik itu, ada sebuah dilema ketika hubungan sosial dan komunikasi tersebut tidak lagi mengarah pada saling mengerti dan timbal balik yang dirasakan salah satu atau masing-masing pihak terasa jomplang. Ini barulah satu kasus di sebuah desa kecil dan terdalam provinsi Lampung. Belum lagi kita kemudian menyadari bahwa akan ada saja konflik yang seolah tak ada habisnya di belahan bumi manapun itu.
Boleh jadi kasus semacam ini yang terus berkelainan dan dalam tataran kehidupan sosial dan berbudaya masyarakat kita dipantik dari kecemburuan dan stigma negatif yang tak kunjung usai dan belum diketemukan jalan temunya. Adapun boleh jadi hal ini akan semakin pelik ketika ditarik pada wilayah masyarakat awam. Baik yang berada di perkotaan, wilayah urban, demikian pula mereka yang ada di perdesaan. Belum lagi jika kita meneropong dilema ini dari sekup lebih sempit. Semisal masyarakat yang memiliki keyakinan/agama yang sama namun memiliki standar kebudayaan atau sub-kultur berbeda masih saja berpeluang menimbulkan konflik. Dari ini kita bisa berkaca dan membaca lebih jauh pada konflik sub-kultur yang baru saja terjadi. Dimana terdapat 14 siswa di salah satu SMP di Solo dikeluarkan pihak sekolah karena yang bersangkutan terjangkit HIV. ${ }^{1}$ Sebenarnya hal ini bermula dari ketakutan segelintir orang tua murid lainnya yang merasa anak mereka berkemungkinan tertular. Pada kasus lain kita juga tentu masih mengingat

\footnotetext{
${ }^{1}$ Kumparan.com, 14 Siswa di Solo Dikeluarkan dari Sekolah karena HIV/AIDS, https://kumparan.com/@kumparannews/14-siswadi-solo-dikeluarkan-dari-sekolah-karena-hiv-aids1550224798129577849 . diakses pada 15 Februari 2019 pukul 23. 27 WIB.
} 
akan pembubaran pondok pesantren Waria di Kotagede, Yogyakarta oleh beberapa oknum yang mengaku dari salah satu ormas islam. ${ }^{2}$

$$
\text { Penulis melihat problema ini }
$$
berangkat dari stigma negatif yang tidak kunjung ditengahi dan diusahakan jalan keluarnya, semisal memberikan pendidikan dan pemahaman kepada mereka yang masih memiliki stigma-stigma ini. Tentunya, hal ini tidak hanya berlaku dalam wilayah hubungan antar kultur dan sub-kultur, namun bisa pula terjadi dan amat memungkinkan pada umat beragama. Meskipun kita juga tidak bisa memungkiri bahwa ini tidak hanya disebabkan oleh stigma saja. Namun lebih jauh lagi ada beragama motif dan latar belakang pemicu. Sehingga, alih-alih kebudayaan dan agama menjadi jalan terang bagi kehidupan manusia yang lebih baik, justru kedua masterpiece ini dijadikan kambing hitam oleh segelintir orang yang berkepentingan di baliknya. Memuai pemicu atau akar masalah timbulnya konflik ini, gambaran untuk ini bisa kita lihat dari beragam sendi-sendi kehidupan manusia yang sangat dinamis. Setidaknya kita bisa mencatat dengan mencurigai walaupun hanya sebatas tesa saja bahwa akar masalah konflik ini berangkat dari diferensiasi keyakinan; polarisasi kepentingan; tujuan yang saling

\footnotetext{
${ }^{2}$ BBC.com, Pesantren Waria di Yogyakarta ditutup, $\quad \mathrm{LBH} \quad$ Protes, https://www.bbc.com/indonesia/berita indonesia/2 016/02/160225 indonesia ponpes waria ditutup. diakses pada 15 Februari 2019 pukul 23. 27 WIB. Kumparan.com, Pesantren al-fatah Menuntun Waria di Persimpangan iman, https://kumparan.com/@kumparannews/pesantrenal-fatah-menuntun-waria-di-persimpangan-iman. diakses pada 15 Februari 2019 pukul 23. 27 WIB.
}

menyudutkan pihak lain; kepentingan politik; perlindungan hukum yang masih mentah; stratifikasi sosial; ekonomi; dan masa lalu ${ }^{3}$. Perlu dicatat bahwa concern dari paper ini tidak membahas motif di luar budaya dan agama. Mengingat akan banyak ruang dan waktu yang dibutuhkan dalam penulisan dan pembahasannya. ${ }^{4}$

\section{Pembahasan}

Hubungan sosio-kultural manusia yang terbilang sangat dinamis dari waktu ke waktu memang sangat mengagumkan. Kendati demikian, penciptaan ruang dan kekayaan intelektual yang dikembangkan sedemikian maju berupa kebudayaan perlu ditinjau manfaat yang bisa dihadirkan guna kemaslahatan umat manusia. Termasuk pengelolaan pada hubungan dari masingmasing budaya dan agama yang ada di dalam kehidupan manusia. Memang kedahsyatan kemampuan manusia dalam melakukan dan membentuk formasi tidak dapat dilakukan makhluk hidup lain. Akan tetapi, tidak jarang bahwa kekayaan budaya dan agama yang ada

\footnotetext{
${ }^{3}$ Lihat zainal Said, Konflik Sosial Keagamaan Islam Non-mainstream dalam Masyarakat Majemuk di Indonesia, Jurnal AlUlum Vol. 12: 2, 2012, hlm. 429-432. Marsudi Utoyo, Akar Masalah Konflik Keagamaan di Indonesia, Jurnal Lex Librium Vol. III: 1, Desember 2016, hlm. 371-373. St. Aisyah BM, Konflik Sosial dalam Hubungan Umat Beragama, Jurnal Dakwah Tabliq Vol. 15: 2, Desember 2014, hlm. 192-202.

${ }^{4}$ Paper ini hanya memberikan gamabran kecil dan terbilang abstrak akan usaha-usaha dalam menemukan jalan tengahd alam beragma penyelesaian konflik yang tidak secara praktis bsia dilakukans ekarang. Namun, gamabarn yang diberikan oleh penulis di sini berupa abstraksi jangka panjang berupa rencana yang bisa diterapkan oleh lapisan masyarakat kita.
} 
menjerumuskan manusia untuk melakukan tindakan stereotip satu sama lain. Saling memisahkan diri dan menganggap agama dan kebudayaannya paling superior.

Perilaku semacam ini yang lantas mendorong manusia untuk tidak lagi memiliki hasrat saling mengenal satu sama lain dan belajar apa kiranya yang dimiliki dan dikuasai oleh kelompok atau golongan lain. Menyoal hubungan ini, penulis terlebih dahulu memperkenalkan bahasan ini pada pemahaman singkat atas tiga tema yang seakan nampak sama, namun sangat amat jelas berbeda satu dengan lainnya. Setidaknya kita mulai memahami kata kunci dari multikultural, lintas budaya dan antarbudaya. Sehingga pemahaman tidak akan keliru tentang tema kebudayaan dan agama tidak menyorong kita pada pertukaran yang mampu meleburkan nilai sejati dari budaya dan agama yang ada dengan menyalurkan sistem dan kepercayaan baru yang selama ini kita ketahui nyaris dan acap kali ditolak oleh sebagian besar manusia dan dianggap tabu atau sesat.

\section{Multikultural sendiri menegaskan} bahwa hal yang penting untuk diperhatikan bahwa sebuah wilayah memiliki kemungkinan budaya yang heterogen dan saling membaur. Namun, hal ini tidak lantas memaksa masingmasing budaya untuk saling melebur. Sedangkan dalam pemahaman lintas budaya, kita diarahkan pada padnangan bahwa ada interaksi di sini yang menunjukkan komparasi budaya yang satu dengan yang lainnya. Komparasi ini juga mengarahkan pada penyandingan dan melihat bagaimana norma salah satu budaya nampak bagi budaya yang dominan. Dalam proses komunikasi lintas budaya, ada saja peluang perubahan yang bisa dialami oleh individu yang melakukan kontak dengan mereka yang berbudaya berbeda. Inilah yang nantinya akan mendorong terjadinya akulturasi. Selanjutnya adalah komunikasi antarbudaya yang bisa dipahami bahwa toleransi menjadi nilai utama dalam sebuah komunikasi dengan peluang saling tukar dan menghormati. Perlu dicatat bahwa selain toleransi, dalam komunikasi antarbudaya sendiri sangat dibutuhkan kesadaran akan resiprositas dan kesetaraan.

Akan tetapi, masih banyak catatan kecil dan besar dari relasi ini yang perlu dibahas dan dicamkan oleh kita. Terutama yang berhubungan dengan kaitan antar budaya satu dan lainnya dan agama satu dengan yang lainnya. Mempertanyakan apa maksud sebuah hubungan itu adalah hal yang sama sekali wajar adanya. Sehingga pemahaman manusia tidak lagi tersesat dan mengarah pada destruksi sosial, budaya, dan keagamaan serta konflik yang berkepanjangan. Maksudnya di sini bahwa kita diajarkan untuk mengenal toleransi. Namun akan beda ceritanya jika toleransi dan pengenalan itu masuk terlampau jauh ke dalam tindakan yang tidak lagi mengindahkan batas-batas tertentu dalam hubungan umat beragama dan berbudaya. Yang sangat ditakutkan adalah pembauran agama satu dengan lainnya dengan menganggap hal-hal berat sebagai suatu kewajaran dan tidak lagi menimbulkan dosa. Ini akan baik-baik saja jika pemahaman kita 
hanya pada batas pembelajaran dan pemahaman guna mengerti dan menghormati apa saja yang diamini oleh orang di luar kita.

Misalnya, jika kita membawa pembahasan ini pada kasus HIV saja. ODHA (Orang dengan HIV/Aids) bisa dikatakan orang-orang yang membangun sub-kultur dari mereka yang menganggap diri sebagai manusia bersih dan tak pantas berdekatan dengan orang yang berpenyakitan. Demikian stigma negatif selama ini dan memang ini telah mengalami pengikisan secara perlahan. Ada resistensi yang perlu diungkapkan dan penerimaaan dari lingkungan sosial ODHA. Bahkan ODHA sendiri tidak lagi memandang perlu dikasihani dan diakui keberadaan mereka jika semua hanya berlandaskan belas kasihan. ${ }^{5}$ Kasus semacam ini juga memberikan gambaran bahwa sub-kultur yang masih dianggap tabu oleh sebagian masyarakat kita. Ketabuan ini setidaknya bisa dilihat bahwa hubungan yang buruk sebelumnya dan juga kesadaran akan kesetaraan adalah biang keladinya. Untuk itulah kebutuhan akan resolusi atas hal kecil dan besar semacam ini diperlukan. $^{6}$

${ }^{5}$ Lihat Mugiarjo, Atribusi Komunikasi atas Keterbukaan Diri ODHA dengan Kerabat Dekat, Skripsi, tidak diterbitkan, Yogyakarta: Komunikasi dan Penyiaran Islam, FDK UIN Sunan Kalijaga, 2017.

${ }^{6}$ Sebagai gambaran lain, lihat juga Mary Grace Antony, On the Spot: Seeking Acceptance and Expressing Resistance through the Bindi, Journal of International and Intercultural Communication, 3:4, 2010, hlm. 346-368, DOI: 10.1080/17513057.2010.510606
Marry Jane Collier menawarkan konsep bagi pemecahan permasalah konflik melalu peace-building yang pernah ia alami ketika menjadi bagian dari International Peace Initiative (IPI). Dalam tawarannya itu, Marry menegaskan bahwa yang amat perlu diperhatikan dalam edukasi dan upaya memahamkan masyarakat dalam pembangunan perdamaian adalah berkutat pada refleksi dan praktik dari refleksi itu. Kedua hal ini juga tidak bisa dilepaskan dari kesadaran bahwa dalam kehidupan berbudaya dan beragama manusia guna melerai pertikaian perlu menyadari dan mempertimbangkan keberadaan hak-hak istimewa masing-masing manusia dan budaya serta agama. Di samping itu, Mary juga menyadari bahwa posisi status, ekuitas, inklusi, dan keadilan menjadi amat penting untuk diadakan dan dipertahankan. Keywords dalam kerangka konseptual Mary ini secara ringkas ada 4 hal yakni Intersecting structural and relational dimensions, Intersecting structural and personal dimensions, Intersecting relational and personal dimensions, Cultures, interculturalities, and dances with difference. ${ }^{7}$ Di sini dalam membangun usaha dalam mewujudkan penciptaan kedamaian, konsep yang ditawarkan oleh IPI ini mencoba mengikat dimensi personal, relasional, dan struktural. Dimana ketiga dimensi ini jika

\footnotetext{
${ }^{7}$ Mary Jane Collier, An Intercultural Peacebuilding Framework: Extending the Conversation through a Focus on Connections, dalam Sudeshna Roy dan Ibrahim Seaga Shaw, ed, Communicating Differences Culture, Media, Peace and Conflict Negotiation, (London: Palgrave Macmillan, 2016), hlm. 15-27.
} 
dilihat saling berpengaruh satu sama lain. Sehingga tautan dari msing-masing dimensi menentukan jalan keluar pemecahan amsalah dan peneluran solusi-solusi melalui dialog antar umat beragama dan budaya. Sebagaimana sisi personal dengan kebutuhan hubungannya menentukan masing-masing cara dan jalan agar hubungan itu dapat dilakukan sedemikian rupa. Lebih lanjut, bahwa sistem struktural yang ada di sekup kecil dan besar komunitas masyarakat kita juga tidak lepas dari peran dalam menengahi dan memfasilitasi kebutuhan akan dimensi-dimensi ini. Dengan kata lain, kinerja hubungan ini tidak dapat ditumpukan pada satu aspek dan dimensi saja. Namun usaha untuk menerapkan cara yang siklikal dan holistik adalah sangat niscaya dan dibutuhkan. Dengan demikian, kita bisi menyadari bahwa budaya dan keberagaman berbagai segi ini dapat dinikmati dengan baik. Seolah kita mampu menari dan hanyut dalam keindahan hubungan antar dan lintas budaya dan agama yang telah ada.

Sebagai sebuah jalan dalam mengadakan edukasi sejak dini dan pengenalannya pada generasi penerus dalam hal menyadari bahwa keberagaman merupakan hal yang amat sangat niscaya hadir di tengahtengah masyarakat yang sangat sosialis dalam mempertahankan hidupnya. Demikian pula bahwa edukasi dengan beragam cara mampu dihadirkan. Selain dengan pengenalan dan menanamkan ilmu-ilmu agama pada generasi penerus. Jalan tengah bagi pembangunan perdamaian atas komunikasi lintas dan antarbudaya dan agama di Indonesia sendiri dapat dilakukan dengan menumbuhkembangkan kecintaan pada local wisdom masing-masing daerah. Kita tentu tahu dan pernah mendengar banyak pepatah yang dihasilkan pendahulu kita dari sabang hingga merauke yang penulis ringkas mengajarkan kita untuk hidup berdampingan. ${ }^{8}$ Selain itu juga kesatuan, gotong royong, kesadaran akan cinta kasih dan sebagainya sudah dihadirkan oleh leluhur kita agar bisa digunakan sebagai bekal dalam mendayagunakan kekayaankekayaan kita sebagai bangsa yang sanggup menopang beragamnya kepercayaan dan kebudayaan yang ada. Salah satu pertayaan yang timbul adalah mengenai mereka walaupun segelintir masih tetap sudi melakukan tindakan ekstrimis dengan tidak sungkan menyakiti pihak lain atas dasar perbedaan. Padahal agama dan budaya leluhur kita secara gamblang kita sadari tidak mengajarkan pada saling menyakiti dan menimbulkan perpecahan. Inilah bahwa edukasi sangat menjadi penting melalui aksi menjembatani setiap kutub budaya dan agama yang berbeda melalui komunikasi.

Maka dari itu, pemahaman akan keberadaan manusia yang sejak dulu sangat multikultur perlu digalakkan dan ditanamkan pada generasi ke generasi. Sehingga manusia tidak lagi latah dan mengeksklusifkan diri dan kelompoknya sendiri. Pembauran-pembauran

\footnotetext{
${ }^{8}$ Edison Munthe, Intercultural Competence In Indonesian Context, dalam Helmut Weiss, ed., Intercultural And Inter-Faith Communication, (Tt, Sipcc, 2006), hlm. 49-50. Diakses melalui laman www.sipcc.org, pada tanggal 13 Februari 2019 pukul 10.00 WIB.
} 
ini mengajak kita sadar bahwa manusia sekali lagi tidak mampu memenuhi apapun yang ia inginkan tanpa berpangku-tangan dengan kemampuan orang lain. Pertukaran sosial dan budaya kita akan terus berlangsung dan saling mengisi. Pun demikian dengan berbagai ilmuilmu agama yang bisa dilestarikan manfaatnya dalam dimensi hidup manusia.

Sari dari ilmu-ilmu agama dan budaya ini bisa kita lihat juga dari ketersediaan segudang medium komunikasi dalam pemahaman dan komunikasi antar dan lintas budaya dan agama. Setidaknya kita bisa melihat bahwa musik mampu meleburkan perbedaan itu menjadi satu. Kita lihat bagaimana musisi internasional beraliran Ragae yakni Alpha Blondy and the Solar System melakukan kampanye perdamaian di belahan bumi teruatma konflik yang sarat politik dengan mengorbankan budaya dan agama. Seketika juga kita tidak bisa berhenti mencucurkan air mata tatkala konflik ini sangat mengiris hati menyaksikan kucuran darah tersebar kemana-mana. Media-media ini memberikan ruang hidup yang sangat baik dalam menggalakkan penciptaan perdamaian. Musik, seni, sastra, pendidikan, sepakbola tidak mengenal kasta dan perbedaan latar belakang agama dan budaya. Hal-hal ini hanya mengenal kesatuan dan ikatan emosi yang kuat dalam menikmati kesatuan itu. Tidak ada lagi diri kita yang lain selain musik yang didendangkan, kecuali kenikmatan sastra dan seni. Pendidikan pun tidak lagi menyoal apa agama dan budaya peserta didiknya, pendidikan seharusnya lebih bertolak dari kesadaran kesetaraan hak untuk sama-sama belajar dan mampu. ${ }^{9}$ Adapun, dalam sebuah ayat Al-Qur'an, Al-ikhlas sekalipun kata ikhlas tidak disebutkan sama sekali di dalamnya, namun di balik itu adalah bagaimana manusia mampu ikhlas dengan menanggalkan kepentingan diri sendiri. Kecuali Allah saja sebagai yang Maha pengampun di seluruh jagat.

Di dalam pandangan ajaran islam yang ada pada Al-Qur'an. Sekiranya sebuah hubungan baik antar dan lintas budaya dan agama bisa dilacak pada beberapa ayat. Salah satunya adalah QS. al-Mumtahanah ayat $8 \mathrm{di}$ bawah ini:

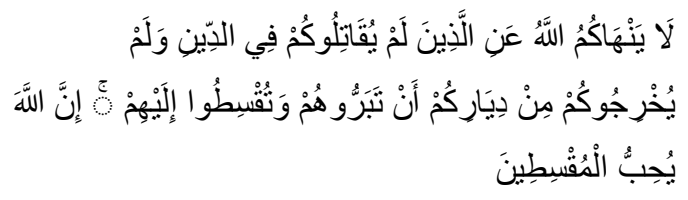

"Allah tidak melarang kamu untuk berbuat baik dan berlaku adil terhadap orangorang yang tiada memerangimu karena agama dan tidak (pula) mengusir kamu dari negerimu. Sesungguhnya Allah menyukai orang-orang yang berlaku adil" (alMumtahanah:8).

Mengacu pada sebab turunnya ayat ini, dapat dilihat bahwa terdapat kejadian dimana perselisihan dalam hal keyakinan (agama) antara anak dan ibu. Imam Bukhari meriwayatkan bahwa dari Asma binti Abu Bakar yang berkata "Suatu hari, ibu saya mengunjungi saya. Ketika itu, ia terlihat dalam

${ }^{9}$ From medium to meaning: The evolution of theories about media, religion, and culture, dalam Stewart M. Hoover, et all, ed., Religion, Media and Culture, (New York: Taylor \& Francis e-Library, 2006), hlm. 27-44. 
kondisi cenderung (kepada islam). Saya lalu bertanya kepada Rasulullah tentang apakah saya boleh menyambung silaturahmi dengannya? Nabi SAW, lalu menjawab, " $Y a$, boleh." Berkenaan dengan peristiwa inilah, Allah SWT lalu menurunkan ayat di atas. ${ }^{10}$

Selain daripada argumen dari asbabun nuzul ayat di atas, mengenai hubungan komunikasi dari orang yang berbeda latar belakang juga bisa kita lihat dari salah satu tafsir al-Misbah QS. Al-Mumtahanah(8) karya Quraish Shihab yang menjelaskan bahwa dalam hubungan umat manusia. Perbedaan latar belakang, misalnya agama tidak menjadi soal selama itu tidak mengarah pada perbuatan untuk saling mencelakai dan merusak hubungan yang ada. Misalnya yang di dalam ayat tersebut sebagai “pengusiran' dan 'memerangi'. Inilah yang turut diurai oleh Quraish Shihab bahwa kata 'tabarruhum' dapat diartikan bahwa Allah SWT memberikan jalan berupa izin kepada umat manusia untuk menyelenggarakan hubungan baik dengan sesama manusia selama perbuatan itu tidak menimbulkan hal-hal negatif bagi umat islam. ${ }^{11}$ Ini menandakan bahwa jalan terang ke arah pembangunan hubungan yang baik dalam pandangan islam sendiri memang dilegalkan. Namun, ada yang perlu diperhatikan dan dipertimbangkan oleh manusia dengan adanya ini bahwa keberlangsungan hubungan yang ada baik jika

10 Jalaludin As-Suyuthi, Sebab Turunnya Ayat Al-Quran, terj. Tim Abdul Hayyie, (Jakarta: Gema Insani, 2008).

${ }_{11}$ M. Quraish Shihab, Tafsir al-Mishbah, Pesan, Kesan dan Keserasian Al-Qur'an, (Jakarta: Lentera Hati, 2003), vol. 14, hlm. 168-169. dicatat sebagai salah satu alat atau medium guna memperkokoh pondasi keberagaman yang ada di indonesia. Dengan kata lain, hubungan baik ini tidak dimanfaatkan demi persekutuan guna menjatuhkan umat beragama satu dan yang lainnya. Pun demikian dengan hubungan antar dan lintas budaya. Termasuk mencampur hal-hal yang tidak harus dicampur sangatlah tidak dianjurkan dan hal ini justru akan mengarah pada perongrongan hubungan ini, misalnya pencampuran hubungan dalam sekup ritual keagamaan. Toh, setiap umat beragama memiliki pondasi sendiri yang mengatur tentang ritual yang tidak seharusnya dicampur-aduk.

Mengulik akan ini, Griffin berusaha menegaskan bahwa komunikasi, apapun bentuk dan taksonominya, bukanlah sebuah cara untuk menjadikan kita saling mengakui dan menyamanakan makna dan pemahaman. Komunikasi tidak berhak dan mampu menjangkau hal-hal tersebut. Namun, komunikasi mampu menjembatani perbedaaan yang ada dengan usaha untuk saling mengerti dan menghormati. Pengakuan-pengakuan atas opini dan pemikiran orang lain dapat diupayakan melalui komunikasi itu sendiri. Sehingga, dalam berbagai dialog kebudayaan dan antarumat beragama, ketika pemaksaan pendapat dan keyakinan pada pihak lain. Tidak dapat lagi ia disebut sebagai dialog ataupun komunikasi.

\section{Simpulan}

Dalam komunikasi lintas dan antarbudaya dan agama, mungkin saja kesalahan terbesar kita adalah melakukan 
penyunatan atas peluang orang lain dalam mengutarakan pemikirannya. Sehingga pernyataan atau pemikiran yang seharusnya hadir secara utuh menjadi grompal dan penuh dengan lubang dan menjadikannya buruk sama sekali. Ini adalah hak yang dalam hubungan multikultur dan keberagamaan kita perlu untuk dipenuhi. Kesetaraan adalah keniscayaan dalam perbedaan. Pelanggaran yang tidak ditindak lanjuti ini akan semakin mendera kita jika seolah memang sedang tidak terjadi apaapa dan menganggap wajar ha-hal semacam ini. Sedangkan kita sadar bahwa manusia dengan berbagai latar belakang berbeda memiliki masing-masing perspektif. ${ }^{12}$

Demikianlah komunikasi memberikan jalan agar setiap perspektif ini dapat ditampung dan dipelajari oleh masing-masing. Kita perlu menandai pula pada pembicaraan yang sangat amat penting mengagungkan kejujuran dalam pendapat. Kepada siapa pernyataan itu ditujukan dan oleh siapa pernyataan itu diungkapkan, pun alasan pengungkapan dan isi dari pernyataan tersebut. Lebih lanjut dalam komunikasi antar dan lintas budaya dan agama kita perlu sadari bahwa ada peluang ketika bias mampu hadir di dalamnya seakan jendela yang mampu menjadi kaca. Padahal kita sama-sama tahu bahwa bayangan yang dihasilkan tidaklah cukup memberikan refleksi yang apik akan perspektif yang kita inginkan. Belum lagi jika kita bericara pada

${ }^{12}$ Lihat When Dialogue Goes Wrong, dalam Jane Idleman Smith, Muslims, Christians, and the Challenge of Interfaith Dialogue,(New York: Oxford University Press, Inc, 2007), hlm. 83-100. tataran ideologi dan mengapa ideologi itu digunakan.

Medium komunikasi sebagaimana yang telah disinggung sebelumnya mampu menyediakan ruang dalam menjembatani carut-marutnya hubungan kita selama ini. Tergantung, medium apakah yang kita pilih dalam menengahi. Bahkan media apapun bisa saja terpolarisasi kepentingannya. Sehingga ini akan membawa buruknya sebuah hubungan semakin tambah pelik lagi. Pendidikan untuk kepentingan bersama ini setidaknya bisa diinisiasi oleh mereka yang memiliki peluang dalam memutuskan kebijakan dan kekuatan menyediakan ruang serta keberadaan medium komunikasi yang mampu dikonseptualisasikan sedemikian rupa dalam memberikan informasi yang berharga bagi anak bangsa.

\section{Daftar Pustaka}

Antony, Mary Grace. 2010. On the Spot: Seeking Acceptance and Expressing Resistance through the Bindi, Journal of International and Intercultural Communication, $\quad 3: 4$. DOI: $10.1080 / 17513057.2010 .510606$

As-Suyuthi, Jalaludin. 2008. Sebab Turunnya Ayat Al-Quran, terj. Tim Abdul Hayyie. (Jakarta: Gema Insani).

$$
\begin{aligned}
& \text { BBC.com, Pesantren Waria di Yogyakarta } \\
& \text { ditutup, } \quad \text { LBH } \\
& \text { https://www.bbc.com/indonesia/berita } \\
& \text { indonesia/2016/02/160225_indonesia } \\
& \text { ponpes_waria_ditutup. diakses pada } \\
& \text { 15 Februari 2019 pukul 23. 27 WIB. } \\
& \text { Kumparan.com, Pesantren al-fatah } \\
& \text { Menuntun Waria di Persimpangan } \\
& \text { iman, } \\
& \text { https://kumparan.com/@kumparannew } \\
& \text { s/pesantren-al-fatah-menuntun-waria- } \\
& \text { di-persimpangan-iman. diakses pada } \\
& \text { 15 Februari 2019 pukul 23. } 27 \text { WIB. }
\end{aligned}
$$


BM, St. Aisyah. 2014. Konflik Sosial dalam Hubungan Umat Beragama. Jurnal Dakwah Tabliq Vol. 15: 2, Desember.

Hoover, Stewart M. et all,ed.. 2006. Religion, Media and Culture. (New York: Taylor \& Francis e-Library).

Kompas.com, Idap HIV/AIDS, 14 Siswa Dikeluarkan dari Sekolahnya, https://regional.kompas.com/read/201 9/02/14/19200061/idap-hivaids-14siswa-dikeluarkan-dari-sekolahnya. diakses pada 15 Februari 2019 pukul 23. 27 WIB.

Kumparan.com, 14 Siswa di Solo Dikeluarkan dari Sekolah karena HIV/AIDS, https://kumparan.com/@kumparannew s/14-siswa-di-solo-dikeluarkan-darisekolah-karena-hiv-aids-

1550224798129577849. diakses pada 15 Februari 2019 pukul 23. 27 WIB.

Mugiarjo. 2017. Atribusi Komunikasi atas Keterbukaan Diri ODHA dengan Kerabat Dekat. Skripsi. tidak diterbitkan, Yogyakarta: Komunikasi dan Penyiaran Islam, FDK UIN Sunan Kalijaga.

Munthe, Edison. 2006. Intercultural Competence In Indonesian Context, dalam Helmut Weiss, ed., Intercultural And Inter-Faith Communication, (Tt, Sipcc). Diakses melalui laman www.sipcc.org, pada tanggal 13 Februari 2019 pukul 10.00 WIB.

Roy, Sudeshna dan Ibrahim Seaga Shaw, ed, 2016. Communicating Differences Culture, Media, Peace and Conflict Negotiation. (London: Palgrave Macmillan).

Said, Zainal. 2012. Konflik Sosial Keagamaan Islam Non-mainstream dalam Masyarakat Majemuk di Indonesia. Jurnal Al-Ulum Vol. 12: 2.

Shihab, M. Quraish. 2003. Tafsir al-Mishbah, Pesan, Kesan dan Keserasian AlQur'an, , vol. 14. (Jakarta: Lentera Hati).
Smith, Jane Idleman. 2007. Muslims, Christians, and the Challenge of Interfaith Dialogue. (New York: Oxford University Press, Inc,).

Utoyo, Marsudi . 2016. Akar Masalah Konflik Keagamaan di Indonesia. Jurnal Lex Librium Vol. III: 1, Desember. 